ACTA UNIVERSITATIS LODZIENSIS

FOLIA OECONOMICA 5(325) 2016

http://dx.doi.org/10.18778/0208-6018.325.02

Joanna Małecka*

\title{
THE ROLE OF THE CAPITAL MARKET IN FINANCING SMES - THE DEVELOPMENT AND SIGNIFICANCE OF NEWCONNECT AS A POTENTIAL SOURCE OF FINANCING FOR SMALL AND MEDIUM-SIZED ENTERPRISES
}

\begin{abstract}
One of the primary objectives of every enterprise is rapid development which, in the conditions of a competitive economy, enables attaining the best possible position on the market. The realization of this objective usually requires incurring investment expenditures, which means finding adequate sources of funding. For entrepreneurs from the SME sector, these are often their own funds; however, intense development also leads to the possibility of using external sources of financing. Selecting a source is certainly a strategic issue. The stock exchange offers a solution by organizing the issue of securities. By concentrating market demand for financial instruments offered by issuers, it is an ideal source of obtaining capital on favourable terms. Public issue enables more reliable access to potential investors and obtaining higher issue prices. Skilful use of such opportunities can provide the company with funds for development and, in a manner consistent with the stated objective, improve the market position of the company. So why do so few companies utilize the main tool of the capital market in Poland? The article presents the Warsaw Stock Exchange as a credible institution with a very high potential for growth, particularly in Central and Eastern Europe, focusing on the market nearest to small and medium-sized enterprises - NewConnect, showing the current state of Polish entrepreneurs' interest in the exchange as a potential source of external financing.
\end{abstract}

Keywords: WSE, NewConnect, stock exchange, SME, firm size.

JEL: G10, G12, G29, L11, L25.

\section{INTRODUCTION}

A free market economy is characterized by a functioning financial market, which has become an ambiguous concept since it covers several aspects of various markets. The total value of the global financial market is constantly increasing. In 2012, it reached USD 225 trillion $^{1}$ (McKinsey Global Institute 2011, as cited in Płókarz 2013: 16). Because of the many meanings of the term in eco-

\footnotetext{
* Politechnika Poznańska, Wydział Inżynierii Zarządzania, joanna.a.malecka@ doctorate.put.poznan.pl

${ }^{1}$ USD 12 trillion in 1980, USD 56 trillion in 1990.
} 
nomics, it is assumed that the financial market is understood as a place where companies seek funds to finance operations. In this case, the money market is gaining attention when making short-term investments (up to one year). Only thoughts of long-term investments, contributing to the development of a company, draw the attention of entrepreneurs towards the capital market and the issue of stocks and bonds. The capital market is a market of financial instruments, known as medium- and long-term, whose redemption period is at least one year or is not specified. Due to their nature, these instruments are primarily used to finance investments, and rarely can they satisfy the current needs of enterprises. Capital market instruments have, as a rule, the nature of a security. Capital recipients prefer long-term capital as a source of financing (Płókarz 2013: 131), as it has the same meaning for small, medium and large companies. SMEs, which are classified according to their size in the literature and the European Union (Cassar, Holmes 2003: 123-147; Gregory et al. 2005: 382-392; Art. 104-106, Journal of Laws 2004 No. 173, item 1807; Annex 1 of the Commission Regulation (EC) No 364/2004, OJ L 124 of 20.5.2003: 36), mark their contribution to the global economy through structural changes and setting the framework for socioeconomic development (Bass 2006: 10-11), while also affecting major macroeconomic indicators (see: Grzywacz 2012; Jaworski 2010). They determine the trend of economic development, especially visible through changes in local or regional markets (Bera 2010: 338; Strużyński 2004: 19).

A properly and effectively functioning capital market is one of the main economic pillars of the state. It mobilizes capital through the transformation of savings into investments, enables its adequate allocation by properly defining financial needs and directing the flow of capital resources to sectors of the economy with a high investment capacity, it enables the valuation of capital and risk through market assessments of the company's value and the identification of hazards associated with its operations. All this leads to an increase in the transparency of business transactions, increasing their flexibility and innovation.

The capital market concerns trading in securities, and the principal place of such transactions is the stock market. In Poland, the meeting place for investors who want to buy stocks and enterprises that want to raise capital for development through the issue of shares is the Warsaw Stock Exchange. Securities affirm the right to a specified property right, purchased with the aim to achieve concrete financial benefits (profit). The exchange is a liquid tool that facilitates the meeting of supply and demand, where excess capital ready to be invested meets those seeking capital for investment.

The main division of the capital market is into the primary and secondary markets. The primary market deals with the issue of stock or other securities. The issue represents the first sale of shares, directly from their owner, whom we call the issuer. Each entity authorized to issue various types of securities may 
issue them repeatedly. A characteristic feature here is supplying the issuer with capital obtained through the sale of securities. We talk about the secondary market when it comes to sale-purchase transactions with investors who have already acquired shares (the so-called second-hand deals) that are subject to the current valuation ensuring the liquidity of investments. It represents the most important segment because it reflects the actual price of securities and their value which is shaped by current market conditions. It also supplements the primary market, as it allows to resell the shares acquired initially on conditions that best suit the original investor.

It is also important to understand the difference between acquiring capital for development on the public market and the private market. The issue of shares by a company is not in fact equivalent to listing them on the stock exchange. In the case of an issue addressed to a specific group of people (e.g. employees), we are talking about trading on the private market. Only trading on the public market, ensured through an offer reaching a wide audience of potential investors who should have access to information concerning the financial condition, allows listing on the primary market of the Warsaw Stock Exchange.

Markets for small and medium-sized enterprises can function as separate floors run by stock exchanges as part of the stock market or as stand-alone exchanges (WSE 2015). In practice, however, independent SME exchanges are rare, and most floors dedicated to them are operated by stock exchanges. Microentrepreneurs, who are the most abundant among enterprises from the SME sector, are also able to take advantage of this source of financing through programs aimed at the smallest entities that focus their businesses around innovation and modern industries in the industrial and services sectors, the so-called start-ups (see: Blair, Marcum 2015: 249-265; Cassar 2004: 261-283; Fourati, Affes 2013: 244-254). A market dedicated to small and medium-sized enterprises is the NewConnect market, which will be supervised by the WSE until 03.07.2016 ${ }^{2}$. Despite the initial assumptions that this market will concentrate on innovative sectors, such as IT, new technologies, eco-energy, life sciences, companies from more traditional industries also trade there. So why do so few Polish enterprises take up the opportunity to raise capital for development through this market? Why do only few entrepreneurs take advantage of the capital market? More liquidity associated with money market instruments is probably one of the reasons (Luczka 2013; Bielawska 2005), but the development that can be achieved by using funds raised through the stock exchange is much greater (Małecka 2015b). Perhaps it is incomplete knowledge about the NewConnect market, its opportunities and performance since 2007 that constitutes a barrier affecting the current

${ }^{2}$ Due to the provisions of the EU Market Abuse Regulation (MAR) this condition will change on 03.07.2016. 
degree of interest in these solutions. The article identifies the main characteristics of the Polish stock exchange that make it the best developing market in Central and Eastern Europe and those of NewConnect - a market primarily intended for small and medium-sized enterprises.

\section{WARSAW STOCK EXCHANGE AS THE MOST DYNAMIC MARKET IN CENTRAL AND EASTERN EUROPE}

The public market and the derivative market are the most prestigious forms of functioning on the capital market. They are becoming of increasing importance in real economic processes in all developing economies of the world. On the public market, securities are offered to a wide range of potential investors. This may be in the form of a stock exchange or in the form of an over-the-counter (OTC) market (Czekaj 2008: 16). In a properly functioning market economy, this market should be a natural stage in the development of a company as well as an effective source of securing additional sources of financing. Companies offering their shares in a public offering have the ability to reach a wide audience of potential customers - from small investors to investment funds. With the status of a listed company, they also gain the prestige associated with membership in an elite group of companies, which is positively perceived by the business environment and, in the case of the SME sector, has a direct impact on the quality of cooperation with banks. The futures market is a derivatives market, the part of the financial market on which futures contracts are entered into. The objects to be traded are contracts for transactions that will take place at a specified date in the future. The underlying instrument, that is the price of a product, is determined at the time of entering into a contract.

The Warsaw Stock Exchange is the biggest and most liquid stock exchange in Central and Eastern Europe. Its position is evidenced by the GDP results achieved in Poland in 2008-2014, which present Poland as the fastest growing economy in Europe, with a balanced and solid financial system, a downward trend in the deficit and public debt in relation to GDP in 2008-2014 and accumulated GDP growth of $24.2 \%$ (Table 1), placing it among leaders in the European Union. The current economic situation results in the strong presence of major global investors as well as a large and growing customer base: issuers, investors, traders, intermediaries, data vendors. The WSE is seen as a vibrant commodity market with significant growth potential. This is confirmed by the results achieved in 2014: domestic market capitalization (EUR 139.1 billion) and value of session equity trading (EUR 49.3 billion) that put the Polish stock exchange in the third place in this part of Europe, right after Moscow and Istanbul (Figure 1). The number of companies on the primary and parallel markets 
amounts to 474 business entities, of which 422 represent domestic companies and 52 foreign issuers, with capitalization of PLN 610 billion (EUR 145.7 billion) and PLN 716 billion (EUR 170.9 billion) respectively (www.gpw.pl, 28.06.2015).

Table 1. GDP in Europe in 2008-2014

\begin{tabular}{|c|c|c|c|c|c|c|c|c|}
\hline EU GDP (\%) & 2008 & 2009 & 2010 & 2011 & 2012 & 2013 & 2014 & $\begin{array}{c}2008-2014 \\
\text { accumulated } \\
\text { GDP }\end{array}$ \\
\hline \begin{tabular}{|l|} 
Poland \\
\end{tabular} & 5.1 & 1.6 & 3.9 & 4.5 & 2.0 & 1.7 & 3.3 & 24.2 \\
\hline Slovakia & 5.8 & -4.9 & 4.4 & 3.0 & 1.8 & 1.4 & 2.4 & 14.4 \\
\hline Malta & 3.9 & -2.8 & 4.3 & 1.4 & 1.1 & 2.7 & 3.5 & 14.8 \\
\hline Sweden & -0.6 & -5.0 & 6.6 & 2.9 & 0.9 & 1.3 & 2.8 & 8.8 \\
\hline Romania & 7.3 & -6.6 & -1.1 & 2.3 & 0.6 & 3.4 & 2.9 & 8.5 \\
\hline Bulgaria & 6.2 & -5.5 & 0.4 & 1.8 & 0.6 & 1.1 & 1.7 & 6.1 \\
\hline Germany & 1.1 & -5.1 & 4.0 & 3.3 & 0.7 & 0.1 & 1.6 & 5.6 \\
\hline Lithuania & 2.9 & -14.8 & 1.6 & 6.0 & 3.7 & 3.3 & 2.9 & 4.1 \\
\hline Austria & 1.4 & -3.8 & 1.8 & 2.8 & 0.9 & 0.2 & 0.3 & 3.5 \\
\hline Belgium & 1.0 & -2.8 & 2.3 & 1.8 & -0.1 & 0.3 & 1.0 & 3.5 \\
\hline Czech Republic & 3.1 & -4.5 & 2.5 & 1.8 & -1.0 & -0.7 & 2.0 & 3.0 \\
\hline Luxemburg & -0.7 & -5.6 & 3.1 & 1.9 & -0.2 & 2.0 & 2.6 & 2.8 \\
\hline UK & -0.8 & -5.2 & 1.7 & 1.1 & 0.3 & 1.7 & 2.6 & 1.2 \\
\hline France & -0.1 & -3.1 & 1.7 & 2.0 & 0.0 & 0.3 & 0.4 & 1.1 \\
\hline EU ( 28 countries) & 0.4 & -4.5 & 2.0 & 1.6 & -0.4 & $\mathbf{0 . 0}$ & 1.3 & 0.2 \\
\hline Estonia & -4.1 & -14.1 & 3.3 & 8.7 & 4.5 & 1.6 & 2.1 & 0.2 \\
\hline Euro area (18 countries) & 0.4 & -4.5 & 1.9 & 1.6 & -0.7 & -0.5 & 0.9 & 0.2 \\
\hline Hungary & 0.9 & -6.8 & 1.1 & 1.6 & -1.7 & 1.5 & 3.6 & -0.1 \\
\hline Netherlands & 1.8 & -3.7 & 1.5 & 0.9 & -1.2 & -0.7 & 0.8 & -0.7 \\
\hline Slovenia & 3.4 & -7.9 & 1.3 & 0.7 & -2.5 & -1.0 & 2.6 & -3.8 \\
\hline Denmark & -0.8 & -5.7 & 1.4 & 1.1 & -0.4 & -0.5 & 1.0 & -4.0 \\
\hline Spain & 0.9 & -3.8 & -0.2 & 0.1 & -1.6 & -1.2 & 1.4 & -4.4 \\
\hline Finland & 0.3 & -8.5 & 3.4 & 2.8 & -1.0 & -1.3 & -0.1 & -4.8 \\
\hline Ireland & -2.2 & -6.4 & -1.1 & 2.2 & 0.2 & 0.2 & 1.7 & -5.5 \\
\hline Portugal & 0.0 & -2.9 & 1.9 & -1.3 & -3.2 & -1.4 & 0.9 & -5.9 \\
\hline Latvia & -2.8 & -17.7 & -1.3 & 5.3 & 5.2 & 4.2 & 2.4 & -6.7 \\
\hline Cyprus & 3.6 & -1.9 & 1.3 & 0.4 & -2.4 & -5.4 & -2.3 & -6.7 \\
\hline Italy & -1.2 & -5.5 & 1.7 & 0.4 & -2.4 & -1.7 & -0.4 & -8.9 \\
\hline
\end{tabular}

Source: WSE 2015: 3. 
Domestic market capitalization in 2014 (in billion EUR)
Value of session equity trading in 2014

(in billion EUR)

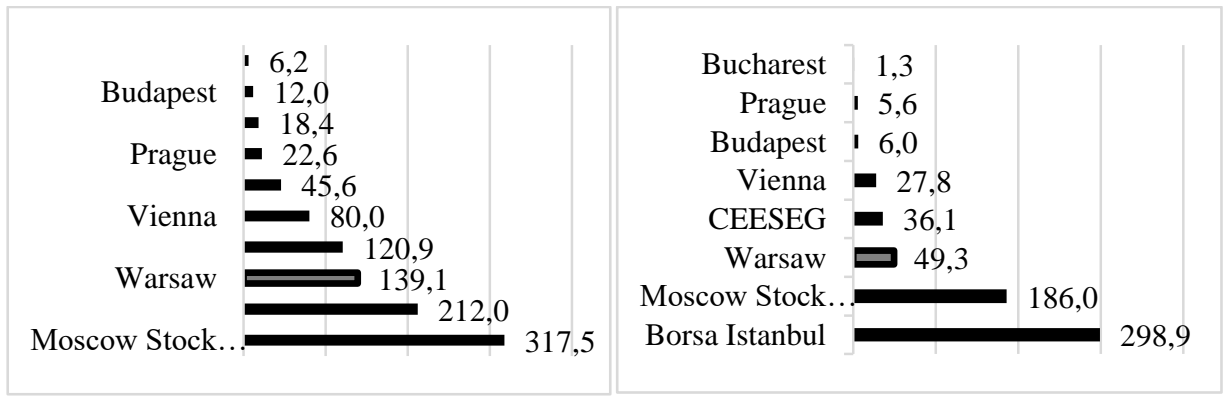

Figure 1. Domestic market capitalization and value of session equity trading in 2014 (in billion EUR)

Source: own elaboration on the basis of WSE 2015: 6.

The Warsaw Stock Exchange is a leading financial instruments exchange in Central and Eastern Europe and one of the fastest growing exchanges in Europe. Its performance is all the more spectacular since the Polish stock market is a financial institution with a relatively short history in comparison to the main players in this area (Figure 2). The first listing took place in Warsaw on 16.04.1991, four days after the stock exchange founding act was signed.

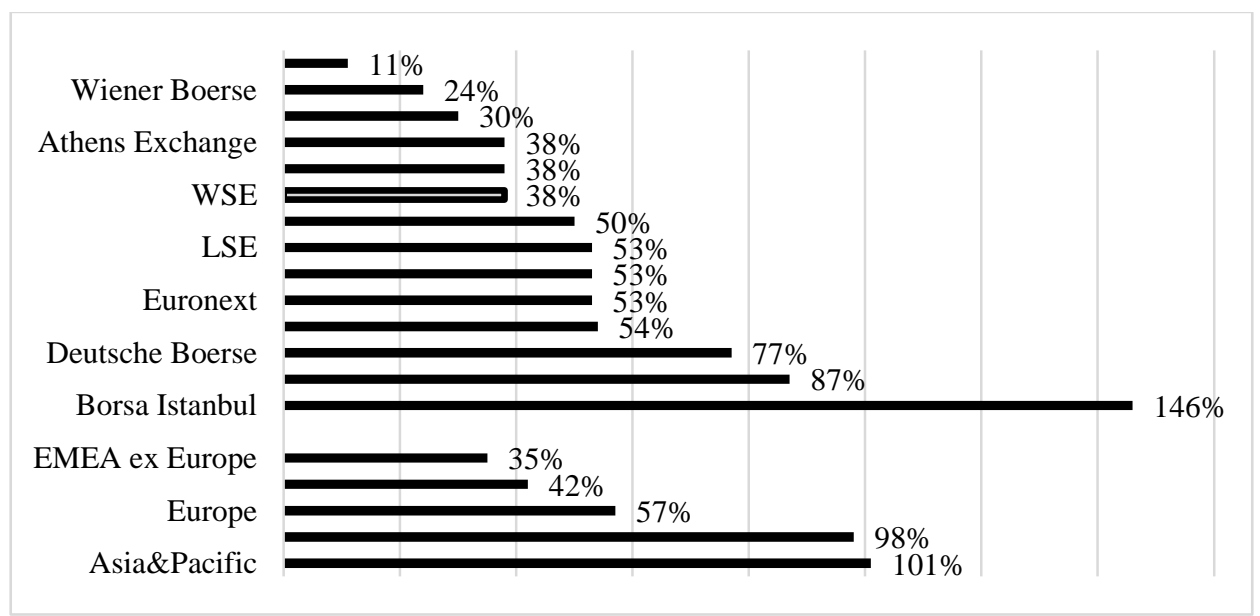

Figure 2. Turnover velocity in 2013

Source: WSE 2015: 6. 
All of the above data should convince the Polish entrepreneur to collaborate with the WSE when making decisions about development and searching for funds to implement deliberate and calculated investments. Even more so, since the characteristics of SMEs often result in those enterprises facing significant discrimination when attempting to obtain a bank loan ${ }^{3}$ (see: Luczka 2013; Bielawska 2005), which usually forces them to prefer internal financing sources (Luczka 2001: 52; Myers 1984: 575-592; Brealey 1999: 668). Why, then, with the existence of an alternative and favourable tool that is the exchange, so few Polish entrepreneurs take advantage of this opportunity? There is a problem of awareness of Polish entrepreneurs and knowledge of the principles of functioning of the capital market and its most important instrument, the exchange, which is still less popular as a means of raising capital for development than banks. The market on which the shares of the smallest companies in Poland are listed is known as NewConnect. Let us, therefore, take a look at the statistics of this very new market ${ }^{4}$ and its main indicators.

\section{EVOLUTION OF THE NEWCONNECT MARKET IN POLAND IN 2007-2015}

Companies wishing to raise capital for development can take advantage of several existing options. Among others, these include the following markets: IPO (Initial Public Offering), PE (Private Equity), Start-Up, as well as NewConnect, where the shares of the smallest companies in Poland are listed (see: Kordela 2013). This market is not regulated, which in practice means fewer formalities and less restrictive conditions regarding the possibility of being listed, as well as low costs of issuing shares ${ }^{5}$ (Bień 2008; Kołosowska 2013). Most companies choosing this market also benefit from rights to private placement, where even the disclosure obligations are limited to a minimum.

After only four years of operation, the Polish NewConnect became the second largest alternative market in Europe in terms of the number of listed companies. When analysing the total capitalization of companies, it takes the ninth place, due to the market segment for micro-enterprises on the European scale (WSE 2015). It has gained interest chiefly among individual investors, who ac-

${ }^{3}$ Companies from the SME sector often receive higher margins, must meet additional requirements regarding security, and are subject to closer scrutiny than large companies.

${ }^{4}$ NewConnect market has operated as an alternative trading system in Poland since 30.08.2007.

${ }^{5}$ The basic requirements include: the legal status of the company (joint-stock or limited joint-stock company), cooperation with an Authorised Adviser and market maker and the preparation of an information document. 
count for $70 \%$ of turnover and accept the increased risk associated with activities on this market in exchange for potentially high returns on their investments ${ }^{6}$. Also Authorised Advisers (AA) are active on NewConnect, with their operations being supervised by the WSE. By the end of 2014, the number of entities with AA status reached 80 .

The number of companies listed on NewConnect since the market's inception increased regularly until 2013, reaching 445 listings (Figure 3).

$$
\begin{aligned}
& -- \text { new listings } \\
& -- \text { delistings } \\
& -- \text { companies }
\end{aligned}
$$

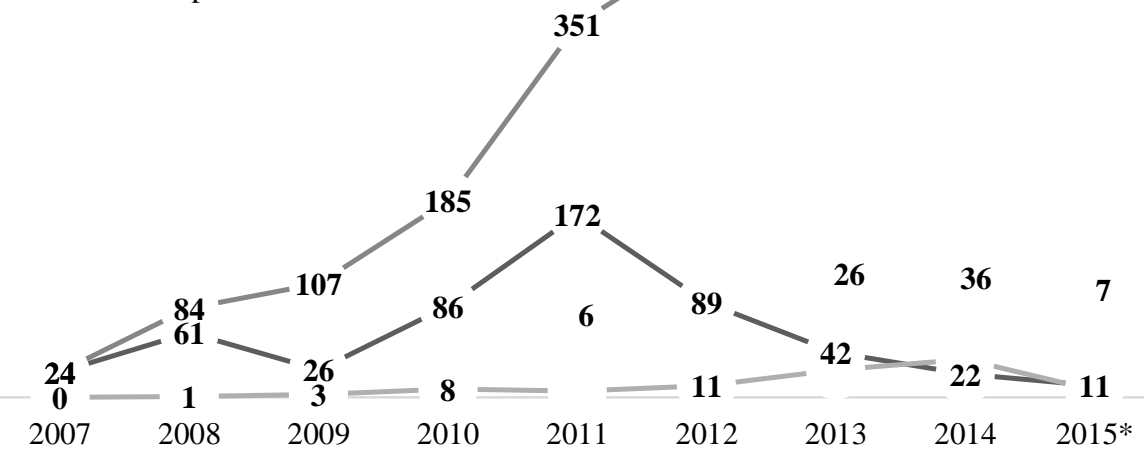

Figure 3. Number of debuts, withdrawals and listings on the NewConnect market in 2007-2015 (*as of 28.06.2015)

Source: own elaboration on the basis of NewConnect, 28.06.2015.

It is worth making a careful analysis of the internal structure of debuts on this market, because the activity of foreign companies is definitely increasing year by year, whereas the contribution of domestic companies is shrinking (Table 2) (Figure 4). In 2014, their participation virtually equalized, and 2015 noted only the activity of foreign entrepreneurs (Figure 3). This statistic has its reflection in the persistent growth of commercial companies with foreign capital in Poland as well as in the growth of limited joint-stock companies (Figure 5) (Table 3) (Małecka 2015: 500-501).

\footnotetext{
${ }^{6}$ NewConnect offers various possibilities for allocating capital, choice of companies based on their size, level of development, business activities and industry specificity, also taking into account market indicators.
} 
Table 2. The share of foreign debuts listed on NewConnect in 2007-2015 [\%]

\begin{tabular}{|c|c|c|c|c|c|c|c|c|c|}
\hline Rok & 2007 & 2008 & 2009 & 2010 & 2011 & 2012 & 2013 & 2014 & $2015^{*}$ \\
\hline $\begin{array}{l}\text { \% udział de- } \\
\text { biutów zagra- } \\
\text { nicznych }\end{array}$ & 0 & 1.6 & 7.7 & 3.5 & 4.1 & 9.0 & 26.2 & 45.5 & 100.0 \\
\hline
\end{tabular}

Source: own elaboration on the basis of NewConnect, 28.06.2015.

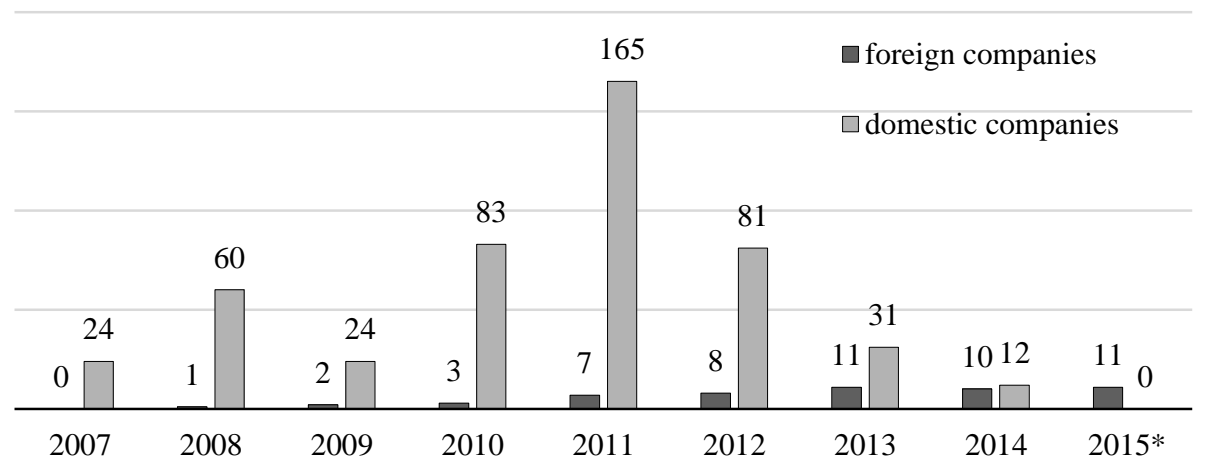

Figure 4. Number of domestic and foreign debuts on the NewConnect market in 2007-2015 (*as of 28.06.2015)

Source: personal elaboration on the basis of NewConnect, 28.06.2015.

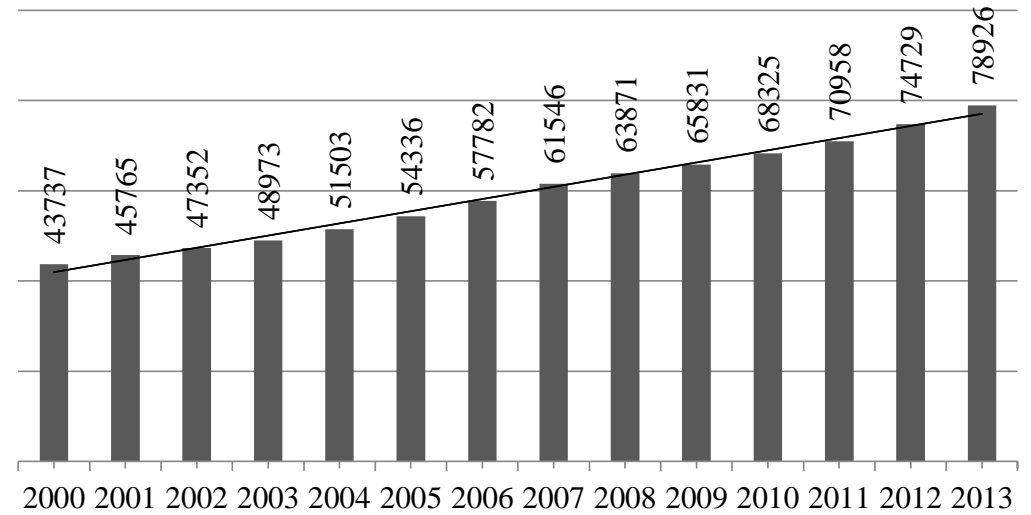

Figure 5. Upward trend in the number of commercial companies with foreign capital

Source: Małecka 2015: 503. in Poland in 2000-2013 
Table 3. Growth of companies according to ownership sector in Poland in 2003-2013 [in \%]

\begin{tabular}{|l|r|r|r|r|r|r|r|r|r|r|r|}
\hline \multicolumn{1}{|c|}{ Year } & 2003 & 2004 & 2005 & 2006 & 2007 & 2008 & 2009 & 2010 & 2011 & 2012 & 2013 \\
\hline $\begin{array}{l}\text { Commercial } \\
\text { companies }\end{array}$ & 6.14 & 5.47 & 4.74 & 5.53 & 6.15 & 4.12 & 5.49 & 6.81 & 6.41 & 8.21 & 9.62 \\
\hline $\begin{array}{l}\text { Join-stock } \\
\text { companies }\end{array}$ & 0.37 & -0.09 & -0.30 & 0.08 & 2.77 & -0.12 & 1.44 & 3.94 & 5.10 & 3.93 & 3.03 \\
\hline $\begin{array}{l}\text { Limited join-stock } \\
\text { companies }\end{array}$ & N/A & N/A & 86.96 & 153.49 & 133.03 & 103.54 & 38.10 & 47.06 & 44.10 & 86.12 & 102.73 \\
\hline
\end{tabular}

Source: own elaboration on the basis of CSO from 2001-2014 (Activity of Non-Financial Enterprises in 2004-2014; Concise Statistical Yearbook of Poland 2011-2014; Statistical Yearbook of Poland 2007-2013; Structural Changes of Groups of Entities of the National Economy in REGON Register 2004-2014).

Considering the number of small and medium-sized enterprises operating in Poland, their quantitative representation on the NewConnect market is scarce, even if narrowed only to companies with a suitable legal status (Małecka 2015: 504). Of all the companies operating in 2012, 99\% (exactly 1794943 ) are companies from the SME sector, of which $95 \%$ are micro-enterprises. Among them, companies that can become potential issuers are those with legal personality, which account for $8 \%{ }^{7}$ of legal persons in this sector. Consequently, the first of the basic conditions imposed by the exchange on potential issuers regarding legal form does not require any transformation in $151655^{8}$ companies in Poland.

The NewConnect market is characterized mainly by two parameters: the number of listed companies (including their debuts) and their value (capitalization, equity turnover, liquidity). In Europe, these two indicators are dominated by the London AIM. That market, however, has operated for much longer than the Polish one, since 1995, and since 2004 it has acted as an MTF. NewConnect is the second alternative market in Europe in terms of the number of listed companies - 431 (at the end of 2014, in terms of: capitalization in the ninth place EUR 2029 million; value of trading in shares in the ninth place - EUR 338 million; liquidity in the sixth place $-17 \%$ ) (Table 4). The nature of NewConnect is directly linked to the specificity of the Polish economy, which is dominated by micro-enterprises. A greater part of the shares usually remains in the hands of the founders, strategic investors or private equity or venture capital firms. With its $17 \%$ liquidity ratio, NewConnect is one of more liquid markets and qualifies as one of those alternative markets in Europe that allow actual trading in shares.

\footnotetext{
${ }^{7}$ According to data taken from the statistics of the CSO, legal persons are not only jointstock companies and limited joint-stock companies.

${ }^{8}$ As above.
} 
Research conducted by J. and K. Kuczowic in 2012 in Silesia ${ }^{9}$ shows that despite the fact that $88 \%$ of surveyed entrepreneurs started their businesses on their own, only $6 \%$ admit that they could sell their companies, with the majority of those respondents being people with higher education. $45 \%$ of respondents may consider such an option in the future, and $42 \%$ of companies are managed by people with higher education. Studies have shown that changes in the approach to business are determined by the level of education of entrepreneurs (Kuczowic J., Kuczowic K. 2013: 369-371). Naturally, to be able to draw full conclusions, a similar study should be extended to the rest of the country and the survey should be expanded by adding a detailed question about the sale of shares in the company. However, this sample has shown how important the qualitative parameters of enterprises are in this sector, since they determine a specific management approach (autocracy of the owner and his/her family) and directly influence the choice of sources of funding of the managed companies.

Table 4. Comparison of the number of selected alternative markets during the years of NewConnect's operation 2007-2014

\begin{tabular}{|l|r|r|r|r|r|r|r|r|}
\hline $\begin{array}{l}\text { Number of companies } \\
\text { of the end of the year: }\end{array}$ & 2007 & 2008 & 2009 & 2010 & 2011 & 2012 & 2013 & 2014 \\
\hline United Kingdom & 1694 & 1550 & 1293 & 1195 & 1143 & 1096 & 1087 & 1104 \\
\hline Poland & $\mathbf{2 4}$ & $\mathbf{8 4}$ & $\mathbf{1 0 7}$ & $\mathbf{1 8 5}$ & $\mathbf{3 5 1}$ & $\mathbf{4 2 9}$ & $\mathbf{4 4 5}$ & $\mathbf{4 3 1}$ \\
\hline Euronext & 119 & 128 & 125 & 155 & 180 & 180 & 184 & 191 \\
\hline Germany & 112 & 115 & 116 & 129 & 134 & 183 & 188 & 169 \\
\hline Luxembourg & & 159 & 202 & 219 & 232 & 233 & 217 & 166 \\
\hline NASDAQ & 126 & 132 & 129 & 124 & 130 & 122 & 131 & 161 \\
\hline Turkey & & & & 31 & 61 & 77 & 89 & 94 \\
\hline Slovakia & & 69 & 65 & 75 & 66 & 65 & 64 & 64 \\
\hline Italy & & & 28 & 34 & 38 & 34 & 32 & 35 \\
\hline Norway & & & & 12 & 17 & 22 & 23 & 26 \\
\hline Spain & 30 & 27 & 25 & 23 & 25 & 23 & 25 & 26 \\
\hline Ireland & & & & & 10 & 23 & 23 & 23 \\
\hline Hungary & 22 & 21 & 19 & 28 & 25 & 22 & 24 & 21 \\
\hline Austria & & & & 6 & 9 & 15 & 19 & 21 \\
\hline Cyprus & & & & & & & 14 & 14 \\
\hline Greece & & & 12 & 14 & 14 & 14 & 14 & 36 \\
\hline
\end{tabular}

Source: WSE 2015: 10.

\footnotetext{
${ }^{9}$ Survey respondents included owners and managers of 146 enterprises employing up to 50 people.
} 


\section{CONCLUSIONS}

A company that is listed on the stock exchange (particularly in the public market) dramatically improves its image perceived by customers. Trust in the company is increased, regardless of industry and type of relationship between entities. The Polish SME sector is dominated by micro-enterprises, while small enterprises' participation is half the EU average. The average survival rate of companies in Poland is 76\%, and after five years of activity on the market it remains at $32 \%$. These indicators have a direct impact on the shape and size of the NewConnect market. By the end of 2014, 431 companies were listed, of which 35 transferred to the Main Market, which shows the potential of small and medium-sized enterprises. When making the courageous decision to liaise with the stock exchange, they themselves notice the even greater opportunities and benefits that come with further and more complex requirements for issuers on the primary market. Compared with the number of SMEs operating on the market, their share in raising capital for development through NewConnect is very small. However, it is rising year by year.

Small enterprises whose owners will decide to take advantage of the stock exchange in their strategic management and business philosophy will be given an additional chance for relatively easy access to capital, enabling development and will raise their prestige. The mentality of Polish small and medium entrepreneurs and their openness to foreign investors are also likely to be of crucial importance here. It seems necessary in this regard to depart from the traditional paradigm of management of small and medium-sized enterprises, mostly as family businesses in which decision-making processes are dominated by people from the group of owners (often family).

A consequence of the development of the capital market and increasing competition is that companies from the SME sector are faced with new challenges, where changes in thinking must be transformed into real changes in the undertaken business activities. The data show that despite the very slow pace, this change is taking place. The capital market for small businesses will grow, but it must be accompanied by the development of management methodology of small business values. The issue should be probed by responding to another question about the rooting of the traditional model functioning in SMEs. Such a model is often a way of life for the owners (family) and reflects in their openness to change and their social attitude towards management and creation of strategic and operational plans that today tend to be unfamiliar terms for entrepreneurs from this sector. This also holds true for the topic of the stock exchange, the principles of its functioning and, most of all, the opportunities it offers. 


\section{REFERENCES}

Bielawska A. (2005), Wyjaśnienie trudności nowo powstających przedsiębiorstw $w$ dostępie do kredytów jako przejaw realizacji teorii asymetrii informacji, [w:] A. Bielawska (ed.), Uwarunkowania rynkowe rozwoju mikro i malych przedsiębiorstw, Szczecin.

Bass H.H. (2006), KMU in der Deutschen Volswirtschaft: Vergangenheit, Gegeneart, "Zukunft", no. 101 , p. 10-11.

Bera A. (2010), Makroekonomiczna pozycja sektora mikro i matych przedsiębiorstw w gospodarce, „Zeszyty Naukowe Uniwersytetu Szczecińskiego. Ekonomiczne problemy usług”, no. 588(51), p. 338 .

Bień W. (2008), Rynek papierów wartościowych, Warszawa, Difin.

Blair E.S., Marcum T.M. (2015), Heed Our Advice: Exploring How Professionals Guide Small Business Owners in Start-Up Entity Choice, "Journal of Small Business Management", vol. 53, Issue 1, p. 249-265, http;//dx.doi.org/10.1111/jsbm.12073.

Brealey R.A. (1999), Podstawy finansowania przedsiębiorstw, PWN, Warszawa.

Cassar G. (2004), The Financing of business start-ups, "Journal of Business Venturing", no. 19, p. 261-283, http://dx.doi.org/10.1016/S0883-9026(03)00029-6.

Cassar G., Holmes S. (2003), Capital Structure and Financing of SMEs; Australian Evidence, “Accounting and Finance", vol. 43, No. 2, p. 123-147, http://onlinelibrary.wiley.com/doi/10.1111/ acfi.2003.43.issue-2/issuetoc.

CSO, Activity of Non-Financial Enterprises in 2004-2012, Warsaw 2006-2014.

CSO, Concise Statistical Yearbook of Poland 2011-2014, Warsaw 2011-2014.

CSO, Statistical Yearbook of Poland 2007-2013, Warsaw 2007-2013.

CSO, Structural Changes of Groups of Entities of the National Economy in REGON Register 2004-2014, Warsaw 2005-2014.

Czekaj J. (2008), Rynki, instrument i instytucje finansowe, PWN, Warszawa.

Fourati H., Affes H. (2013), The Capital Structure of Business Start-Up: Is There a Pecking Order Theory or Reversed Pecking Order?, "Technology and Investment", vol. 4, p. 244-254, http://dx.doi.org/10.4236/ti.2013.4402.

Gregory B., Rutherford M., Oswald S., Gardiner L. (2005), An Empirical Investigation of the Growth Cycle Theory of Small Firm Financing, "Journal of Small Business Management", vol. 43, p. 382-392, http://onlinelibrary.wiley.com/doi/10.1111/j.1540627X.2005.00143.x/epdf.

Grzywacz J. (2012), Kapitat w przedsiębiorstwie i jego struktura, Oficyna Wydawnicza Szkoły Głównej Handlowej, Warszawa.

Jaworski J. (2010), Teoria i praktyka zarządzania finansami przedsiębiorstw, CeDeWu.PL, Warszawa.

Kołosowska B. (2013), Finansowanie sektora matych i średnich przedsiębiorstw ze źródet pozabankowych, CeDeWu.PL, Warszawa.

Kordela D. (2013), NewConnect - rynek giełdowy dla małych i średnich przedsiębiorstw, CeDeWu.PL, Warszawa.

Kuczowic J., Kuczowic K. (2013), Małe przedsiębiorstwa na rynku kapitałowym - dziś i jutro, "Studia Ekonomiczne. Uniwersytet Ekonomiczny w Katowicach", vol. 155, p. 359-374.

Łuczka T. (2001), Kapitat obcy w matym i średnim przedsiębiorstwie. Wybrane aspekty mikroi makroekonomiczne, Wydawnictwo Naukowe PWN, Warszawa.

Łuczka T. (2013), Makro- i mikroekonomiczne determinanty struktur kapitału w matych i średnich przedsiębiorstwach, Wydawnictwo Politechniki Poznańskiej, Poznań.

Małecka J. (2015a), Giełda Papierów Wartościowych w Warszawie jako potencjalne źródło finansowania matych i średnich przedsiębiorstw, [w:] A. Bielawska (ed.) Uwarunkowania rynkowe rozwoju mikro, małych i średnich przedsiębiorstw; Mikrofirma 2015, Wydawnictwo Naukowe Uniwersytetu Szczecińskiego, Szczecin, p. 496-507. 
Małecka J. (2015b), Selected Problems of the Capital Market in Poland, [in:] M. Postuła, J. Turyna (eds.), Finansowe uwarunkowania rozwoju organizacji gospodarczych. Zarzadzanie finansami a efektywność ekonomiczna, Wydawnictwo Naukowe Wydziału Zarządzania Uniwersytetu Warszawskiego, Warszawa, p. 349-362.

Myers S.C. (1984), The Capital Structure Puzzle, “Journal of Finance”, vol. 39(3), p. 575-592.

Płókarz R. (2013), Globalne rynki finansowe, PWN, Warszawa.

Roxburgh Ch., Lund S., Piotrowski J., Mapping global capital markets 2011 (2011), McKinsey Global Institute.

Strużyński M. (2004), Znaczenie małych i średnich przedsiębiorstw $w$ rozwoju regionu - nowe wyzwania, [in:] M. Strużyński (ed.), Małe i średnie przedsiębiorstwa $w$ gospodarce regionu, p. 19, PWE, Warszawa.

WSE (2015), Warsaw Stock Exchange, The most dynamic market in Central and Eastern Europe, p. 3-6.

Articles and laws

Art. 104-106, Act of 2 July 2004 on Freedom of Economic Activity, "Journal of Laws" 2004, No. 173 , item 1807, p. 54.

Art. 104-106, "Journal of Laws" 2004, No. 173, item 1807, p.54; Annex 1 of Commission Regulation (EC) No 364/2004, OJ L 124, 20.05.2003, p. 36.

Annex 1 of Commission Regulation (EC) No 364/2004 of 25.02.2004 (Extract from Commission Recommendation 2003/361/EC of 6 May 2003 concerning the definition of small and medium sized enterprises, OJ L 124, 20.05.2003, p. 36).

Internet sources

gpw.pl [Access 28.06.2015].

newconnect.pl [Access 28.06.2015].

Joanna Małecka

\section{ROLA RYNKU KAPITALOWEGO W FINANSOWANIU MSP - ROZWÓJ I ZNACZENIE NEWCONNECT, JAKO POTENCJALNEGO ŹRÓDŁA FINANSOWANIA MAŁYCH I ŚREDNICH PRZEDSIĘBIORSTW}

Streszczenie. Jednym z podstawowych celów każdego przedsiębiorstwa jest możliwie szybki rozwój, umożliwiający w warunkach gospodarki konkurencyjnej, uzyskanie jak najlepszej pozycji na rynku. Realizacja tego celu wymaga zazwyczaj poniesienia nakładów inwestycyjnych, co oznacza konieczność znalezienie adekwatnego źródła finansowania. Dla przedsiębiorcy z sektora MSP są to często środki własne, jednak intensywny rozwój wiąże się również z możliwością korzystania z zewnętrznych źródeł finansowania. Wybór źródła stanowi z pewnością problem strategiczny. Giełda oferuje jego rozwiązanie poprzez zorganizowanie emisji papierów wartościowych. Koncentrując rynkowy popyt na instrumenty finansowe oferowane przez emitentów, stanowi idealne źródło pozyskania kapitału na korzystnych warunkach. Emisje publiczne umożliwiają wiarygodniejszy dostęp do potencjalnych inwestorów i uzyskanie wyższych cen emisyjnych. Umiejętne wykorzystanie takich możliwości pozwala zapewnić spółce środki na rozwój i w sposób zgodny z założonym celem poprawić pozycję rynkową przedsiębiorstwa. Dlaczego zatem tak mało firm korzysta z głównego narzędzia rynku kapitałowego w Polsce? W artykule zaprezentowano Giełdę Papierów Wartościowych w Warszawie, jako instytucję wiarygodną i z bardzo wysokim potencjałem na rozwój, szczególnie w Europie Srodkowej i Wschodniej, skupiając się na rynku najbliższym małym i średnim przedsiębiorcom - NewConnect, pokazując stan obecny zainteresowania polskiego przedsiębiorcy giełdą, jako potencjalnym źródłem finansowania zewnętrznego.

Slowa kluczowe: GPW, NewConnect, giełda, MSP, wielkość przedsiębiorstwa.

JEL: G10, G12, G29, L11, L25. 